\title{
PENGARUH MODEL PROBLEM BASED LEARNING (PBL) TERHADAP PENINGKATAN KEMAMPUAN KONEKSI MATEMATIS SISWA
}

\author{
Hafsah Adha Diana \\ SMP Muhammadiyah 28 Bekasi, Jl. Kimangunsarkoro, Bekasi; adhadiana@gmail.com
}

\begin{abstract}
Abstrak. Penelitian ini mengkaji pengaruh model PBL dan pembelajaran langsung terhadap peningkatan kemampuan koneksi matematis yang ditinjau dari kemampuan awal matematika siswa SMA Negeri di Bekasi Utara. Penelitian ini merupakan kuasi eksperimen. Kelas eksperimen diberi perlakuan berupa model PBL, sedangkan kelas kontrol berupa model pembelajaran langsung. Populasi penelitian ini adalah siswa SMA Negeri 4 Kota Bekasi kelas XI IPA tahun ajaran 2016/2017 yang berasal dari populasi yang berdistribusi normal, memiliki varians yang sama atau homogen, dan memiliki kesamaan rata-rata. Instrumen yang digunakan terdiri dari tes kemampuan koneksi matematis dan tes kemampuan awal matematika. Sebelum digunakan, instrumen tersebut telah melalui uji validitas isi, validitas konstruk, dan validitas empirik. Analisis data dilakukan dengan uji Anava dua jalur dan uji-t. Berdasarkan hasil penelitian, ditemukan bahwa: (1) kemampuan koneksi matematis siswa yang mendapat pembelajaran model PBL lebih baik dibandingkan siswa yang mendapat pembelajaran model pembelajaran langsung. (2) terdapat interaksi antara model pembelajaran dan kemampuan awal matematika terhadap kemampuan koneksi matematis siswa. (3) kemampuan koneksi matematis siswa dengan kemampuan awal matematika tinggi yang mendapat perlakuan model PBL lebih baik dibandingkan dengan siswa yang mendapat perlakuan model pembelajaran langsung.
\end{abstract}

Kata Kunci. Koneksi matematis, PBL, Pembelajaran Langsung, Kemampuan Awal

\section{THE EFFECT OF PROBLEM BASED LEARNING (PBL) MODEL TOWARDS IMPROVEMENT OF STUDENTS' MATHEMATICAL CONNECTION ABILITY}

\begin{abstract}
This study aims to analyze the effect of PBL and direct learning model towards improvement of mathematical connection ability, anlysed based on the initial mathematics ability of senior high school students at North Bekasi. This is a quasi experiment research. The treatment of PBL model was applied to the experiment class, while the controling class applied a direct learning model. The population of this study was the students of SMA Negeri 4 Kota Bekasi grade XI IPA academic year 2016/2017 whic was a normal population consisting of homogenous students. The instruments used consisted of mathematical connection ability test, initial mathematical ability test. Prior to the aplication, the instrument has passed the test of content validity, construct validity, and empirical validity. Data analysis was done using two-way Anava test and t-test. Based on the research results, it is found that: (1) improvement of student's mathematical connection ability given PBL model treatment is higher than those direct instruction models was applied. (2) there is an interaction between the learning model and the initial mathematical ability to improve students' mathematical connection ability. (3) the improvement of mathematical connection ability of students with high mathematics initial
\end{abstract}


ability to whom PBL model was applied is higher compared to students who got direct learning model treatment.

Keywords. Mathematical Connection, Problem Based Learning

\section{Pendahuluan}

Salah satu mata pelajaran yang diajarkan dari jenjang Sekolah Dasar sampai Perguruan Tinggi adalah matematika. Tujuan mempelajari matematika adalah untuk memberikan penataan nalar dan pembentukan sikap siswa serta juga memberi tekanan pada keterampilan dalam penerapan matematika (Dewi, 2013). Tujuan umum pembelajaran matematika yang direvisi oleh National Council of Teachers of Mathematics (NCTM) mengungkapkan standar proses kemampuan matematis yang harus dikuasai siswa di antaranya: (1) pemahaman (knowing); (2) penalaran (reasoning); (3) koneksi (connections); (4) pemecahan masalah (problem solving); dan (5) komunikasi (communications) (NCTM, 2014). Tercapainya pembelajaran matematika yang berkualitas tersebut tentu harus disertai dengan pemahaman terhadap tujuan-tujuan dari pembelajaran matematika itu sendiri. Berdasarkan beberapa tujuan tersebut, dapat dilihat bahwa salah satu komponen kemampuan standar yang penting dicapai dalam pembelajaran matematika adalah kemampuan koneksi matematis.

"Koneksi matematis merupakan pengaitan antar topik matematika, matematika dengan topik lain, serta pengaitan matematika dengan kehidupan" (Rokhaeni, 2011: 3). Kemampuan koneksi matematis diperlukan siswa karena matematika merupakan satu kesatuan, di mana konsep yang satu berhubungan dengan konsep yang lain. Seperti yang diungkapkan oleh Ostroff, langkah terbaik yang dapat dimulai oleh siswa adalah menemukan kembali apa yang telah dipelajari untuk memahami pemikiran dan ingatan siswa akan pengetahuan yang telah lalu agar dibangun kembali (Ostroff, 2013). Pengetahuan yang sudah dimiliki sebelumnya akan membantu siswa dalam memahami gagasan dan konsep baru. Hal ini senada dengan pernyataan bahwa "koneksi adalah salah satu alasan dibalik pentingnya mengaktivasikan pengetahuan sebelumnya" (Jensen dan Nickelsen, 2008:83). Tujuannya agar pengetahuan yang terdahulu tidak hanya menjadi hafalan semata tetapi mampu menunjang dan memantapkan pengetahuan yang baru guna memudahkan siswa memecahkan suatu masalah.

Melalui koneksi matematis, diharapkan pemikiran dan wawasan siswa akan semakin terbuka terhadap matematika. Tidak hanya terfokus pada topik tertentu saja, tetapi juga berkaitan dengan dispilin ilmu lain dan kehidupan sehari-hari. Kenyataan di lapangan menunjukkan bahwa kemampuan koneksi matematis siswa masih rendah. Hal ini ditunjukkan oleh hasil penelitian Sugiman di SMP diperoleh bahwa tingkat kemampuan koneksi matematis siswa baru mencapai rata-rata 53,8\%, capaian ini tergolong rendah (Sugiman, 2008). Untuk melihat dan mengukur sejauh mana siswa mampu melakukan koneksi matematis, instrumen yang digunakan harus dapat membuat siswa menemukan keterkaitan antar proses dalam suatu konsep matematika, dan membuat siswa menemukan keterkaitan dengan displin ilmu lain atau dalam kehidupan sehari-hari.

Selain dari aspek pembelajaran kemampuan koneksi siswa, ditinjau pula aspek kemampuan awal matematika (KAM) siswa. KAM siswa dikategorikan dalam dua tingkatkan tinggi dan rendah. Kemampuan awal amat penting perananya dalam meningkatkan kebermaknaan 
pengajaran, yang selanjutnya membawa dampak dalam memudahkan proses internal yang berlangsung dalam diri siswa ketika belajar (Uno, 2012).

Berdasarkan penjelasan yang dikemukakan di atas, maka diperlukan pembelajaran yang diharapkan tepat dan mampu meningkatkan kemampuan koneksi matematis siswa. Salah satu model pembelajaran yang berlandaskan teori kontruktivisme adalah Problem Based Learning (PBL). PBL adalah suatu model pembelajaran yang melibatkan siswa untuk memecahkan suatu masalah melalui tahap tahap metode ilmiah sehingga siswa dapat mempelajari pengetahuan yang berhubungan dengan masalah tersebut dan sekaligus memiliki keterampilan untuk memecahkan masalah (Ngalimun dkk, 2016). Model PBL menempatkan situasi masalah sebagai fokus pembelajaran yang menyediakan pengalaman otentik yang mendorong siswa untuk belajar aktif, mengonstruksi pengetahuan dan mengintegrasikan konteks belajar disekolah dan belajar di kehidupan nyata (Amir, 2015). Sehingga siswa tidak saja mempelajari konsep-konsep yang berhubungan dengan masalah tetapi juga metode ilmiah untuk memecahkan masalah tersebut. PBL menuntut aktivitas mental siswa dalam memahami suatu konsep, prinsip, dan keterampilan melalui situasi atau masalah yang disajikan di awal pembelajaran. Situasi atau masalah menjadi titik tolak pembelajaran untuk memahami prinsip dan mengembangkan kemampuan yang berbeda dari pembelajaran pada umumnya.

Penelitian yang dilakukan oleh Permana dan Sumarmo pada tahun 2007 mengatakan bahwa pelaksanaan pembelajaran dengan PBL dapat meningkatkan kemampuan penalaran dan koneksi matematis siswa. Kemampuan koneksi matematis siswa melalui pembelajaran berbasis masalah lebih baik daripada koneksi matematik siswa melalui pembelajaran biasa. Secara rinci, kemampuan koneksi matematik siswa melalui pembelajaran berbasis masalah tergolong kualifikasi cukup. Sedangkan kemampuan koneksi matematik siswa melalui pembelajaran biasa tergolong kualifikasi kurang (Permana dan Sumarmo, 2007).

Berdasarkan penjabaran diatas, maka penelitian ini lakukan dengan tujuan untuk 1) mengidentifikasi pengaruh perbedaan peningkatan kemampuan koneksi matematis siswa yang diberi perlakuan model PBL secara keseluruhan dengan siswa yang diberi perlakuan model pembelajaran langsung; 2) mengidentifikasi interaksi antara model pembelajaran dan kemampuan awal matematika terhadap peningkatan kemampuan koneksi matematis; 3) mengidentifikasi pengaruh perbedaan peningkatan kemampuan koneksi matematis siswa dengan kemampuan awal matematika tinggi yang diberi perlakuan model PBL dengan siswa yang diberi perlakuan model pembelajaran langsung; 4) mengidentifikasi pengaruh perbedaan peningkatan kemampuan koneksi matematis siswa dengan kemampuan awal matematika rendah yang diberi perlakuan model PBL dengan siswa yang diberi perlakuan model pembelajaran langsung.

Kemampuan koneksi matematis yang diukur dalam penelitian ini adalah: (1) Menerapkan matematika dalam kehidupan sehari-hari; (2) Memahami hubungan antar topik matematika;

(3) Mencari hubungan satu prosedur dengan prosedur lain dalam representasi yang ekuivalen;

(4) Menerapkan hubungan konsep matematika dengan topik diluar matematika. 


\section{Metode Penelitian}

Metode yang digunakan dalam penelitian ini adalah metode eksperimen semu (quasi eksperimen). Varibel bebas pada penelitian ini terdiri dari satu variabel aktif dan satu variabel atribut. Variabel aktif adalah model pembelajaran yang terdiri dari model PBL $\left(A_{1}\right)$ dan model pembelajaran langsung $\left(A_{2}\right)$. Sedangkan variabel atributnya adalah kemampuan awal matematika yang terdiri dari kemampuan awal matematika tinggi $\left(B_{1}\right)$ dan kemampuan awal matematika rendah $\left(B_{2}\right)$. Variabel terikatnya adalah kemampuan koneksi matematis siswa. Penelitian ini pada aspek kognitif menggunakan metode eksperimen dengan desain faktorial $2 \times 2$ treatment by level dengan tiga variabel penelitian, yaitu satu variabel terikat dan dua variabel bebas.

Populasi dalam penelitian ini adalah seluruh siswa SMA Negeri di Bekasi Utara dengan akreditasi A yang terdaftar pada tahun ajaran 2016-2017. Sedangkan populasi terjangkau penelitian ini adalah seluruh siswa kelas XI IPA SMAN 4 Bekasi tahun ajaran 2016-2017 berdasarkan purposive sampling karena terdapat kesesuaian antara materi dan waktu terhadap penelitian dan pihak sekolah yang mengizinkan melaksanakan penelitian. Jumlah sampel untuk mengukur kemampuan koneksi matematis siswa pada kelas eksperimen dengan kemampuan awal matematika rendah terdapat 22 siswa dan kemampuan awal matematika tinggi juga 22 siswa. Pada kelas kontrol jumlah siswa dengan kemampuan awal matematika tinggi ada 22 siswa dan pada siswa dengan kemampuan awal rendah juga 22 siswa. Data dalam penelitian ini diperoleh dari hasil pretest dan post-test kemampuan koneksi matematis siswa pada kelas eksperimen dan kelas kontrol dan hasil tes kemampuan awal matematika. Analisis data yang digunakan dalam penelitian ini adalah Anava dua jalur untuk $N$-gain kemampuan koneksi matematis.

Perlakuan yang diberikan tentu berbeda, yaitu perlakuan dengan model PBL pada kelas eksperimen dan perlakuan model pembelajaran langsung pada kelas kontrol. Rancangan kedua perlakuan disajikan dalam Tabel 1 berikut.

Tabel 1. Rancangan Perlakuan Model PBL dan Model Pembelajaran Langsung

\begin{tabular}{|c|c|c|}
\hline & $\mathrm{PBL}$ & Pembelajaran Langsung \\
\hline Materi & Aturan Pencacahan & Aturan Pencacahan \\
\hline Waktu & 90 menit & 90 menit \\
\hline Pertemuan & 8 pertemuan & 8 pertemuan \\
\hline Pretest & $\begin{array}{l}\text { Pretest Kemampuan Koneksi } \\
\text { Matematis }\end{array}$ & $\begin{array}{l}\text { Pretest Kemampuan Koneksi } \\
\text { Matematis }\end{array}$ \\
\hline Pendahuluan & $\begin{array}{l}\text { Mengecek kehadiran siswa dan } \\
\text { meminta siswa untuk menyiapkan } \\
\text { perlengkapan dan peralatan yang } \\
\text { diperlukan, misalnya buku siswa. }\end{array}$ & $\begin{array}{l}\text { Mengecek kehadiran siswa dan } \\
\text { meminta siswa untuk menyiapkan } \\
\text { perlengkapan dan peralatan yang } \\
\text { diperlukan, misalnya buku siswa }\end{array}$ \\
\hline Kegiatan Inti & $\begin{array}{l}\text { Fase 1: Mengorientasikan siswa pada } \\
\text { masalah } \\
\text { Guru memotivasi siswa terlibat aktif } \\
\text { pada aktivitas pemecahan masalah } \\
\text { yang dipilih. Guru Menjelaskan tujuan } \\
\text { pembelajaran, logistik yang } \\
\text { diperlukan. }\end{array}$ & $\begin{array}{l}\text { Fase 1: Orientasi } \\
\text { Guru memberikan kerangka pelajaran } \\
\text { dan orientasi terhadap materi } \\
\text { pelajaran. Kegiatan yang dilakukan } \\
\text { pada fase ini meliputi kegiatan } \\
\text { pendahuluan, menyampaikan tujuan } \\
\text { pembelajaran, dan memotivasi siswa. }\end{array}$ \\
\hline
\end{tabular}




\begin{tabular}{|c|c|c|}
\hline & $\begin{array}{l}\text { Fase } 2 \text { : Mengorganisasikan siswa } \\
\text { untuk belajar } \\
\text { Guru membantu siswa membatasi } \\
\text { dan mengorganisasi tugas belajar } \\
\text { yang berhubungan dengan masalah } \\
\text { yang di hadapi }\end{array}$ & $\begin{array}{l}\text { Fase } 2 \text { : Persentasi/Demonstrasi } \\
\text { Guru menyajikan materi pelajaran, baik } \\
\text { berupa konsep maupun keterampilan. } \\
\text { Kegiatan pada fase ini meliputi: } \\
\text { penyajian materi, pemberian contoh } \\
\text { konsep, pemodelan/peragaan } \\
\text { keterampilan }\end{array}$ \\
\hline & $\begin{array}{l}\text { Fase 3: Membimbing penyelidikan } \\
\text { individu maupun kelompok } \\
\text { Guru mendorong siswa } \\
\text { mengumpulkan informasi yang } \\
\text { sesuai, melaksanakan eksperimen, } \\
\text { dan mencari untuk penjelasan dan } \\
\text { pemecahan }\end{array}$ & $\begin{array}{l}\text { Fase 3: Latihan Terstruktur } \\
\text { Guru melakukan penguatan dengan } \\
\text { memberikan contoh pengerjaan latihan } \\
\text { soal yang terstruktur. }\end{array}$ \\
\hline & $\begin{array}{l}\text { Fase } 4 \text { : Mengembangkan dan } \\
\text { menyajikan hasil karya } \\
\text { Guru membantu siswa merencanakan } \\
\text { dan menyiapkan karya yang sesuai } \\
\text { seperti laporan, video, dan model, } \\
\text { dan membantu mereka untuk berbagi } \\
\text { tugas dengan temannya }\end{array}$ & $\begin{array}{l}\text { Fase 4: Latihan Terbimbing } \\
\text { Guru memberikan soal-soal latihan dan } \\
\text { melaksanakan bimbingan dengan } \\
\text { memonitor proses pengerjaan soal } \\
\text { yang dilakukan siswa. }\end{array}$ \\
\hline & $\begin{array}{l}\text { Fase 5: Menganalisis dan } \\
\text { mengevaluasi proses pemecahan } \\
\text { masalah. } \\
\text { Guru membantu siswa melakukan } \\
\text { refleksi terhadap penyelidikan dan } \\
\text { proses-proses yang digunakan } \\
\text { selama berlangsungnya pemecahan } \\
\text { masalah }\end{array}$ & $\begin{array}{l}\text { Fase } 5 \text { : Latihan Mandiri } \\
\text { Guru memberikan kesempatan kepada } \\
\text { siswa untuk terus berlatih, baik konsep } \\
\text { maupun keterampilan secara mandiri } \\
\text { dengan memberikan tugas-tugas yang } \\
\text { dikerjakan secara individual. }\end{array}$ \\
\hline Penutup & $\begin{array}{l}\text { Guru mengakhiri kegiatan belajar } \\
\text { dengan memberikan pesan untuk } \\
\text { tetap belajar }\end{array}$ & $\begin{array}{c}\text { Guru mengakhiri kegiatan belajar } \\
\text { dengan memberikan pesan untuk tetap } \\
\text { belajar }\end{array}$ \\
\hline Post-test & $\begin{array}{l}\text { Post-test Kemampuan Koneksi } \\
\text { Matematis }\end{array}$ & $\begin{array}{l}\text { Post-test Kemampuan Koneksi } \\
\text { Matematis }\end{array}$ \\
\hline
\end{tabular}

\section{Hasil Penelitian}

Peningkatan kemampuan koneksi matematis siswa dapat dilihat dari rata-rata skor $\mathrm{N}$-gain masing-masing kelompok berdasarkan KAM rendah dan KAM tinggi pada masing-masing kelas eksperimen dan kelas kontrol. Data rata-rata $\mathrm{N}$-gain kemampuan koneksi matematis siswa berdasarkan faktor model pembelajaran dan KAM dapat dilihat dari Gambar 1.

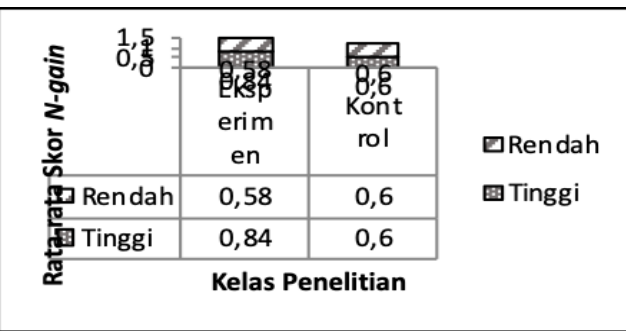

Gambar 1. Diagram Peningkatan Kemampuan Koneksi Matematis pada Kelas Eksperimen dan Kelas Kontrol yang ditinjau dari KAM 
Berdasarkan diagram Gambar 1. di atas dapat dilihat bahwa peningkatan kemampuan koneksi matematis siswa pada kelas eksperimen yang mendapat perlakuan PBL dengan kemampuan awal matematika tinggi yaitu sebesar 0.84 . Sedangkan rata-rata $N$-gain kemampuan koneksi matematis siswa pada kelas kontrol yang mendapat perlakuan pembelajaran langsung dengan kemampuan awal tinggi yaitu sebesar 0.60. Sehingga dapat dikatakan bahwa peningkatan kemampuan koneksi matematis siswa pada kelas eksperimen yang mendapat perlakuan PBL lebih tinggi dibandingkan siswa pada kelas kontrol yang mendapat perlakuan pembelajaran langsung pada kelompok kemampuan awal matematika tinggi.

Rata-rata $N$-gain kemampuan koneksi matematis siswa pada kelas eksperimen yang mendapat perlakuan PBL dengan kemampuan awal matematika rendah yaitu sebesar 0.58. Sedangkan rata-rata $\mathrm{N}$-gain kemampuan koneksi matematis siswa pada kelas kontrol yang mendapat perlakuan pembelajaran langsung dengan kemampuan awal matematika rendah yaitu sebesar 0.60. Sehingga dapat dikatakan bahwa peningkatan kemampuan koneksi matematis siswa pada kelas eksperimen yang mendapat perlakuan PBL lebih rendah dibandingkan siswa pada kelas kontrol yang mendapat perlakuan pembelajaran langsung pada kelompok kemampuan awal matematika rendah.

Setelah uji normalitas dan homogenitas terpenuhi, maka selanjutnya dilakukan uji analisis varian (ANAVA) dua jalur. Jika hasil uji ANAVA dua jalur terdapat interaksi maka dilakukan dengan uji lanjut dengan uji-t. Perhitungan data $N$-gain kemampuan koneksi matematis dengan ANAVA dua jalur dapat dilihat pada Tabel sebagai berikut:

Tabel 2. Hasil Uji ANAVA Dua Jalur Pengaruh Model Pembelajaran dan KAM dengan Interaksi Terhadap Peningkatan Kemampuan Koneksi Matematis

\begin{tabular}{|c|c|c|c|c|c|}
\hline Source & $\begin{array}{c}\text { Type III Sum of } \\
\text { Squares }\end{array}$ & df & $\begin{array}{c}\text { Mean } \\
\text { Square }\end{array}$ & F & Sig. \\
\hline Corrected Model & $1.019^{\mathrm{a}}$ & 3 & .340 & 8.918 & .000 \\
Intercept & 37.689 & 1 & 37.689 & 989.612 & .000 \\
KAM & .392 & 1 & .392 & 10.281 & .002 \\
Model & .290 & 1 & .290 & 7.609 & .007 \\
KAM * Model & .338 & 1 & .338 & 8.863 & .004 \\
Error & 3.199 & 84 & .038 & & \\
Total & 41.907 & 88 & & & \\
Corrected Total & 4.218 & 87 & & & \\
\hline
\end{tabular}

a. R Squared $=.242($ Adjusted R Squared $=.214)$

\subsection{Perbedaan Peningkatan Kemampuan Koneksi Matematis antara Kelas Eksperimen dan Kelas Kontrol}

Berdasarkan Tabel 2. hasil perhitungan ANAVA dua jalur dengan bantuan SPSS 22 pada kedua kelompok data $N$-gain di atas menunjukkan bahwa pada Model nilai Sig. $=0.007<$ $\alpha=0.05$ maka $H_{0}$ ditolak. Hal ini berarti terdapat perbedaan yang signifikan pada peningkatan kemampuan koneksi matematis siswa yang mendapat perlakuan model PBL dengan siswa yang mendapat perlakuan model pembelajaran langsung. Berdasarkan hasil uji$t$ didapat hasil $t_{\text {hit }}=2.758>t$ tabel $=t_{(0.05,86)}=1,66$ maka $\mathrm{H}_{0}$ ditolak. Hal ini berarti bahwa peningkatan kemampuan koneksi matematis siswa yang mendapat perlakuan model 
PBL lebih tinggi daripada peningkatan kemampuan koneksi matematis siswa yang mendapat perlakuan model pembelajaran langsung.

\subsection{Interaksi antara Model Pembelajaran dengan Kemampuan Awal Matematika Terhadap Kemampuan Koneksi Matematis}

Berdasarkan Tabel 2 terlihat pada faktor interaksi antara model pembelajaran dengan kemampuan awal matematika menunjukkan adanya interaksi. Hal ini dapat dilihat pada faktor interaksi antara KAM dengan model pembelajaran yang memiliki nilai Sig. $=0.004<$ $\alpha=0.05$ pada taraf signifikansi $5 \%$ maka $H_{0}$ ditolak. Hal ini menunjukkan bahwa terdapat pengaruh interaksi yang signifikan antara faktor model pembelajaran dan kemampuan awal matematika terhadap kemampuan koneksi matematis siswa. Interaksi antara model pembelajaran dan kemampuan awal matematika terhadap kemapuan koneksi matematis siswa dapat dilihat berdasarkan grafik pada diagram Gambar 2 sebagai berikut:

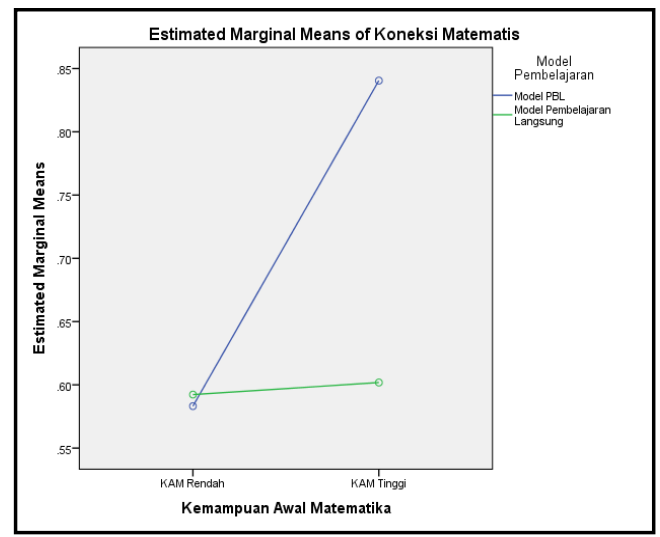

Gambar 2. Interaksi Antara Model Pembelajaran dan Kemampuan Awal Matematika terhadap Kemampuan Koneksi Matematis

Berdasarkan Gambar 2 terlihat bahwa model PBL efektif untuk meningkatkan kemampuan koneksi matematis secara keseluruhan, namun terlihat bahwa pada kemampuan awal matematika rendah peningkatan kemampuan koneksi matematis siswa yang mendapat perlakuan model PBL sedikit lebih rendah dibandingan dengan siswa yang mendapat perlakuan model pembelajaran langsung.

\subsection{Perbedaan Peningkatan Kemampuan Koneksi Matematis pada Kelompok Siswa dengan Kemampuan Awal Matematika Tinggi}

Berdasarkan perhitungan Multiple Comparisons menunjukkan bahwa antara siswa yang mendapat perlakuan model PBL dengan siswa yang mendapat perlakuan model pembelajaran langsung dengan kemampuan awal tinggi memiliki Sig. $=0.00<0.05$ pada taraf signifikansi $5 \%$ maka $H_{0}$ ditolak, hal ini berarti terdapat perbedaan peningkatan kemampuan koneksi matematis siswa antara siswa yang mendapat perlakuan model PBL dengan model pembelajaran langsung pada kelompok siswa yang memiliki kemampuan awal matematika tinggi. Hasil uji- $t$ yaitu $\mathrm{t}$ hitung $=4.097>\mathrm{t}$ tabel $=1.68$, maka tolak Ho. Hal ini berarti peningkatan kemampuan koneksi matematis siswa dengan kemampuan awal matematika 
tinggi yang mendapat perlakuan model PBL lebih tinggi dibandingkan dengan siswa yang mendapat perlakuan model pembelajaran langsung.

\subsection{Perbedaan Peningkatan Kemampuan Koneksi Matematis pada Kelompok Siswa dengan Kemampuan Awal Matematika Rendah}

Berdasarkan perhitungan Multiple Comparisons menunjukkan bahwa antara siswa yang mendapat perlakuan model PBL dan siswa yang mendapat perlakuan model pembelajaran langsung dengan kemampuan awal rendah memiliki Sig. $=0.461>0.05$ pada taraf signifikansi 5\% maka $H_{0}$ diterima, hal ini berarti tidak terdapat perbedaan peningkatan kemampuan koneksi matematis siswa antara siswa yang mendapat perlakuan model PBL dengan model pembelajaran langsung dengan kemampuan awal matematika rendah.

\section{Diskusi}

Berdasarkan hipotesis keempat bahwa kemampuan koneksi matematis siswa dengan kemampuan awal matematika rendah yang mendapat perlakuan model PBL lebih rendah dibandingkan dengan siswa yang mendapat perlakuan model pembelajaran langsung. Namun, berdasarkan perhitungan tidak terdapat perbedaan peningkatan kemampuan koneksi matematis siswa dengan kemampuan awal rendah yang mendapat perlakuan model PBL dengan siswa yang mendapat perlakuan model pembelajaran langsung.

Model PBL menganut teori konstruktivisme. Sesuai dengan teori konstruktivisme, pada model ini siswa diharapkan dapat mengkonstruk pengetahuannya sendiri melalui masalah. Model ini membuat siswa belajar dengan memanfaatkan pengetahuannya dan informasi dari lingkungan sekitar untuk menyelesaikan masalah yang diberikan. PBL merupakan model yang efektif untuk mengembangkan proses berfikir ke tingkat yang lebih tinggi. PBL mengorientasikan pembelajaran terhadap suatu masalah. Pembelajaran ini membantu siswa untuk memproses informasi yang sudah jadi dalam benaknya dan menyusun pengetahuan mereka sendiri tentang dunia sosial dan sekitarnya. Pembelajaran ini cocok untuk mengembangkan pengetahuan dasar maupun kompleks. Model PBL menuntut siswa untuk aktif selama proses diskusi pemecahan masalah berlangsung.

Siswa yang memiliki kemampuan awal matematika tinggi lebih mengeksplor pengetahuannya dengan mengaitkan segala kemampuan yang dimiliki dengan mata pelajaran lain ataupun dengan antar topik matematika serta akan mencoba menyelesaikan masalah yang diberikan dengan berbagai prosedur sedangkan siswa dengan kemampuan awal matematika rendah karena tidak memiliki pengetahuan awal yang cukup sehingga mereka merasa kesulitan dalam menyelesaikan masalah mengenai koneksi matematis. Karena kemampuan awal matematika merupakan faktor yang penting dalam kemampuan koneksi matematis. Siswa dengan kemampuan awal rendah dalam menyelesaikan masalah hanya mendengarkan dan menerima materi dari temannya. Adanya diskusi kelompok tersebut dapat membantu siswa dengan kemampuan awal rendah. Karena dengan diskusi kelompok siswa dengan kemampuan awal rendah tidak memiliki rasa sungkan untuk bertanya kepada temannya. Kegiatan tersebut sama pada model pembelajaran langsung, siswa dengan kemampuan awal matematika rendah hanya menerima materi yang diberikan oleh guru.

Perbedaannya jika siswa dengan kemampuan awal matematika rendah yang mendapat perlakuan model PBL mendapat penjelasan dari teman sekelompoknya dan siswa yang 
mendapat model pembelajaran langsung mendapat penjelasan dari guru. Kelebihan model pembelajaran langsung adalah mudah untuk direncanakan dan digunakan, sedangkan kelemahan utamanya adalah dalam mengembangkan kemampuan-kemampuan, proses-proses, dan sikap yang diperlukan untuk pemikiran kritis dan hubungan interpersonal serta belajar kelompok (Ngalimun dkk, 2016). Berdasarkan paparan tersebut maka dapat dikatakan jika tidak terdapat perbedaan peningkatan kemampuan koneksi matematis siswa dengan kemampuan awal matematika rendah yang mendapat perlakuan model PBL dengan siswa yang mendapat perlakuan model pembelajaran langsung.

\section{Kesimpulan dan Saran}

\subsection{Kesimpulan}

Berdasarkan hasil penelitian dan pembahasan mengenai pengaruh model Problem Based Learning (PBL) terhadap disposisi matematis dan peningkatan kemampuan koneksi matematis, beranjak dari hasil penelitian yang telah dijabakan, maka dapat diperoleh kesimpulan sebagai berikut:

1. Perbedaan peningkatan kemampuan koneksi matematis siswa yang mendapat perlakuan model PBL secara keseluruhan lebih tinggi dibandingkan dengan siswa yang mendapat perlakuan model pembelajaran langsung.

2. Terdapat interaksi antara model pembelajaran dan kemampuan awal matematika terhadap peningkatan kemampuan koneksi matematis siswa.

3. Perbedaan peningkatan kemampuan koneksi matematis siswa dengan kemampuan awal matematika tinggi yang mendapat perlakuan model PBL lebih tinggi dibandingkan siswa yang mendapat perlakuan model pembelajaran langsung.

\subsection{Saran}

Berdasarkan kesimpulan diatas, terdapat beberapa saran guna penelitian lebih lanjut yaitu guru sebaiknya memperhatikan pengelolaan kelas dan pengalokasian waktu selama proses pembelajaran berlangsung agar penerapan model pembelajaran dapat maksimal dan semua siswa aktif dalam pembelajaran. Dalam penerapan model PBL, guru harus cermat memilih masalah yang pemecahannya membutuhkan kemampuan berpikir siswa yang ekstra agar siswa merasa tertantang dalam memecahkan masalah tersebut. Guru diharapkan dapat membimbing siswa untuk menyadari kegunaan matematika dikarenakan dalam matematika tidak hanya terjadi keterkaitan secara internal saja (antar cabang, konsep, atau topik matematika) tapi juga terdapat keterkaitan secara eksternal yaitu antara matematika dengan disiplin ilmu lain dan dengan kehidupan sehari-hari. 


\section{Daftar Pustaka}

Amir, M. Taufiq. (2015) Inovasi Pendidikan Melalui Problem Based Learning: Bagaimana Pendidik Memberdayakan Pemelajar di Era Pengetahuan. Jakarta: PT Adhitya Andrebina Agung.

Dewi, Nuriana Rachmani. (2013). Peningkatan Kemampuan Koneksi Matematis Mahasiswa Melalui Brain-Based Learning Berbantuan Web. Prosiding SNMPM Universitas Sebelas Maret Vol.1 pp. 283-292. Surakarta: UNS.

Jensen, Eric dan LeAnn Nickelsen. (2008). Deeper Learning: 7 Strategi Luar Biasa untuk Pembelajaran yang Mendalam dan Tak Terlupakan. Terj. Benyamin Molan. Jakarta: PT Indeks.

NCTM, 1989, Curriculum and Evaluation Standards for School Mathematics. (Online), (Tersedia:http://www.krellinst.org/AiS/ textbook/manual/stand/ NCTME_stand.html. (November).

Ngalimun, dkk. (2016). Strategi dan Model Pembelajaran. Yogyakarta: Aswaja Pressindo.

Ostroff, Wendy L. (2013). Memahami Cara Anak-Anak Belajar: Membawa Ilmu Perkembangan Anak ke dalam Kelas. (Terjemahan: B. Sendra Tanuwidjaja). Jakarta: PT Indeks.

Permana, Yanto dan Sumarmo. (2007). Mengembangkan Kemampuan Penalaran dan Koneksi Matematis Siswa SMA melalui Pembelajaran Berbasis Masalah. Jurnal, Bandung: Universitas Pendidikan Indonesia.

Rokhaeni, Arsinah. (2011). Penerapan Model CORE dalam Pembelajaran Matematika untuk Meningkatkan Kemampuan Koneksi Matematis Siswa. Jurnal Pendidikan Matematika, pp. 1-12. Universitas Pendidikan Indonesia.

Sugiman. (2008). Koneksi Matematik dalam Pembelajaran Matematika di Sekolah Menengah Pertama. Jurnal Pendidikan Matematika FMIPA UNY.

Uno, Hamzah B. (2012). Orientasi Baru Dalam Psikologi Pembelajaran. Jakarta: Bumi Aksara 